Маријола Обрадовић ${ }^{1}$, Катарина Васиљевић-Пантелић², Јасмина Радојловић

\title{
RISKY BEHAVIOR, INJURIES AND POISONING ELDERLY PEOPLE
}

Marijola Obradović, Katarina Vasiljević-Pantelić, Jasmina Radojlović

\section{Сажетак}

Здравствени ризиии су особине, догађаји или навике који повећавају вероватноћу јављања болести, повреда или смрти код људи. Фактори ризика су: личне карактеристике појединиа (демографске, здравствене, сочиоекономске укључујући и понашане) и еколошке (физичке, биолошке и сочиоекономске).

Основни циль рада је сагледавање ризичних понашања старих особа и повреда $и$ тровања. У оквиру основног ииља сагледавање је извршено по територијалним деловима Србије, типу насеља, полу и узрасту, те образовном нивоу и имућном стағу.

Реализујући основни ичиь извршена је анализа података екстензивног анкетног истражсивања које је у два наврата (2000. и 2006. године) извршио Институт за јавно здравље Србије.

Стареособеимајуположен возачки испит u возе разна превозна средства, најчешће бицикл, аутомобил и трактор. При вожни у добром проиенту не користе заштитна средства, затим не користе светла при вожни ноћу, не вежу појас, возе под утииајем алкохола, прекорачују дозвољену брзину и користе мобилни телефон при вожъи. Због таквог ризичног понамања саобраћајни удес својом кривицом имало је 2.6\% старих особа; најчешћи узрочи удеса били су непоштоваье саобраћајних прописа, лоши временски услови, брза вожна и умор, Поред повреда, старе особе су имале и тровања,

\section{Summary}

Health risks are characteristics, events or habits that increase the probability of illness, injury or death in humans. Risk factors are personal characteristics of the individualc (demographic, health, socio-economic, including behavior); environmental characteristics (physical, biological and socio-economic).

The main objective of this paper is to assess the risk behaviors of the elderly and injury and poisoning. In the basic objective insight was made by territorial parts of Serbia, settlement type, gender and age, and educational level and prosperous state.

Realizing the main objective, an analysis of extensive survey data was made, which has twice been performed by the Institute of Public Health of Serbia (2000. and 2006).

Elderly people have a driver's license and drive a variety of vehicles, mostly bicycle, car and tractor. When driving in a good percentage do not use protective device, then do not use lights when driving at night, do not wear seat belts, driving under the influence of alcohol, exceeding the speed limit and use a cell phone while driving. Because of this risky behavior by their fault car accident had 2.6\% of the elderly, the most common causes of accidents were non-compliance with traffic regulations, bad weather conditions, speeding and fatigue. Besides injuries, the elderly had the poisoning, which are mainly caused by food, less chemicals and drugs. When injuries first

\footnotetext{
' Мр мед. др Маријола Обрадовић, Завод за здравствену заштиту радника „Железнице Србије“ Београд.

2 Др Катарина Васиљевић-Пантелић, Дом здравља Уб.

${ }^{3}$ Мр мед. Јасмина Радојловић, Висока медицинска школа струковних студија „Милутин Миланковић“, Београд, Црнотравска 27.
} 
која су углавном изазвана храном, ређе хемикалијама и лековима. При повређивању прва помоћ није примењена код четвртине повреЂених. Исход повреда и тровања је излечење (61.3\%) и побољшане (32.8\%), док је само 4.7\% имало трајне последице.

Кључне речи: Ризично понашағе, повреде, тровање, стара лища aid is not applied in fourth injured. The out come of injury and poisoning is cured (61.3\%) and improved (32.8\%), while only $4.7 \%$ had a lasting impact.

Keywords: Risky behavior, injuries, poisoning, elderly people

\section{УВОД}

3 дравствени ризици су особине, догађаји или навике који повећавају вероватноћу јављања болести, повреда или смрти код људи. Ако је човек изложен дуже времена деловању фактора ризика, адаптивни механизам се замара и исцрпљује и одбрамбена способност организма опада, па се равнотежа човека са околином ремети и јавља се болест. Фактори ризика су:

- Личне карактеристике појединца - демографске, здравствене, социоекономске, укључујући и понашање;

- Еколошке карактеристике - физичке, биолошке и социоекономске ${ }^{(1,2)}$.

Између човека и његове околине постоји сталан динамичан однос у облику интеракције међусобних утицаја, па је зато и главни циљ здравствене заштите да се човек задржи у равнотежном положају, а ако то није могуће, онда што раније откривање обољења и ефикасно лечење и рехабилитација ${ }^{(3,4)}$.

Социјална околина је својствена човеку и њу чине заједнице људи са својом културом која укључује знања, веровања, обичаје, традицију, науку, уметност, понашање, начин одевања, начин исхране, друштвеноекономске односе, урбанизацију, индустријализацију, разне делатности, породичне односе, односе у радној, школској и спортској заједници, однос у месној заједници, здравствену заштиту и здравствену службу ${ }^{(5,6)}$.
Болести савременог човека - хроничне масовне незаразне болести дегенеративног карактера (кардиоваскуларне, повреде, дијабет, опструктивна болест плућа и многе друге), које настају као последица деловања фактора ризика из околине и због негативно формираног обрасца понашања који исто тако настаје под утицајем социјалне околине - породица, радна заједница ${ }^{(7,8)}$.

Здравље се састоји из биопсихосоцијалних компоненти индивидуе и еколошко-социјалних компоненти околине и произилази из динамичне равнотеже човека и његове околине. Значи, здравље је резултанта ендогених наследних чинилаца и оних који се јављају у току развоја плода пре рођења и егзогених, који окружују човека читавог живота ${ }^{(9)}$.

Фрактура представља делимични или потпуни прекид континуитета кости. Због поремећаја коштане структуре првог и другог реда и присутне остеопорозе, веома често долази до фрактуре код старих људи и при најмањој трауми ${ }^{(10)}$.

\section{ЦИЛ И МЕТОД РАДА}

Основни циљ рада је сагледавање ризичних понашања старих особа и повреда и тровања. У оквиру основног циља сагледавање је извршено по територијалним деловима Србије, типу насеља, полу и узрасту, те образовном нивоу и имућном стању.

Реализујући основни циљ извршена је анализа података екстензивног анкетног истраживања које је у два наврата (2000. и 2006. године) извршио Институт за јавно здравље Србије. 


\section{РЕЗУЛТАТИ И ДИСКУСИЈА}

Старе особе у великом броју имају положен возачки испит - у узрасту 65-69 година $48.7 \%$, а у старијим узрастима нешто мање (табела 1).

Табела 1. Имају положен возачки испит.
Старе особе у добром броју случајева возе неко превозно средство (табела 2). Најчешће возе бицикл (45.9\%), затим аутомобил (29.1\%) и трактор (15.1\%), чак 7.8\% вози мотор. У односу на узраст старе особе у већем броју возе бицикл, мотор и камион.

\begin{tabular}{|c|c|c|c|c|c|c|}
\hline \multirow{2}{*}{ Узраст } & \multicolumn{3}{|c|}{ Број анкетираних } & \multicolumn{3}{c|}{$\%$} \\
\cline { 2 - 7 } & Да & Не & Свега & Да & Не & Свега \\
\hline $65-69$ & 256 & 634 & 890 & 48.7 & 37.5 & 40.2 \\
\hline $70-74$ & 171 & 530 & 701 & 32.5 & 31.4 & 32.6 \\
\hline 75 и + & 99 & 526 & 625 & 18.8 & 31.1 & 28.2 \\
\hline Укупно & 526 & 1690 & 2216 & 100.0 & 100.0 & 100.0 \\
\hline
\end{tabular}

Табела 2. Возила која возе старе особе.

\begin{tabular}{|l|c|c|c|c|c|c|}
\hline \multirow{2}{*}{ Возила } & \multicolumn{3}{|c|}{ Број анкетираних } & \multicolumn{3}{c|}{$\%$} \\
\cline { 2 - 7 } & $65-74$ & 75 и + & Свега & $65-74$ & 75 и + & Свега \\
\hline Бицикл & 341 & 83 & 424 & 44.2 & 54.2 & 45.9 \\
\hline Аутомобил & 237 & 32 & 269 & 30.7 & 20.9 & 29.1 \\
\hline Мотор & 59 & 13 & 72 & 7.7 & 805 & 7.8 \\
\hline Трактор & 117 & 22 & 139 & 15.2 & 14.4 & 15.1 \\
\hline Камион & 13 & 3 & 16 & 1.7 & 2.0 & 1.7 \\
\hline Ролери & 4 & - & 4 & 0.5 & - & 0.4 \\
\hline Укупно & 771 & 153 & 924 & 100.0 & 100.0 & 100.0 \\
\hline
\end{tabular}

Коришћење заштитних средстава при вожњи приказано је на табели 3.

Табела 3. Коришћење заштитних средстава при вожњи.

\begin{tabular}{|l|c|c|c|c|}
\hline \multirow{2}{*}{$\begin{array}{l}\text { Превозно } \\
\text { средство }\end{array}$} & \multicolumn{4}{|c|}{ Добне групе (у \%) } \\
\hline Бицикл & $65-69$ & $70-74$ & 75 и & Свега \\
\hline Ролери & 38.4 & 34.6 & 42.2 & 37.9 \\
\hline Мотор & 0.3 & 0.6 & 1.0 & 0.5 \\
\hline Аутомобил & 4.8 & 5.6 & 4.9 & 5.1 \\
\hline Трактор & 36.6 & 35.7 & 33.4 & 35.8 \\
\hline УКУПНО & 19.9 & 23.5 & 18.5 & 20.7 \\
\hline
\end{tabular}

Из табеле 3. се види да се заштитна средства при вожњи ређе користе - при вожњи бицикла $37,9 \%$, мотора $5.1 \%$, аутомобила $35.8 \%$ и трактора $20.7 \%$.
Погледајмо детаљније у табели четири и ризично понашање старих особа при вожњи. 
Табела 4. Ризично понамање при вожюи.

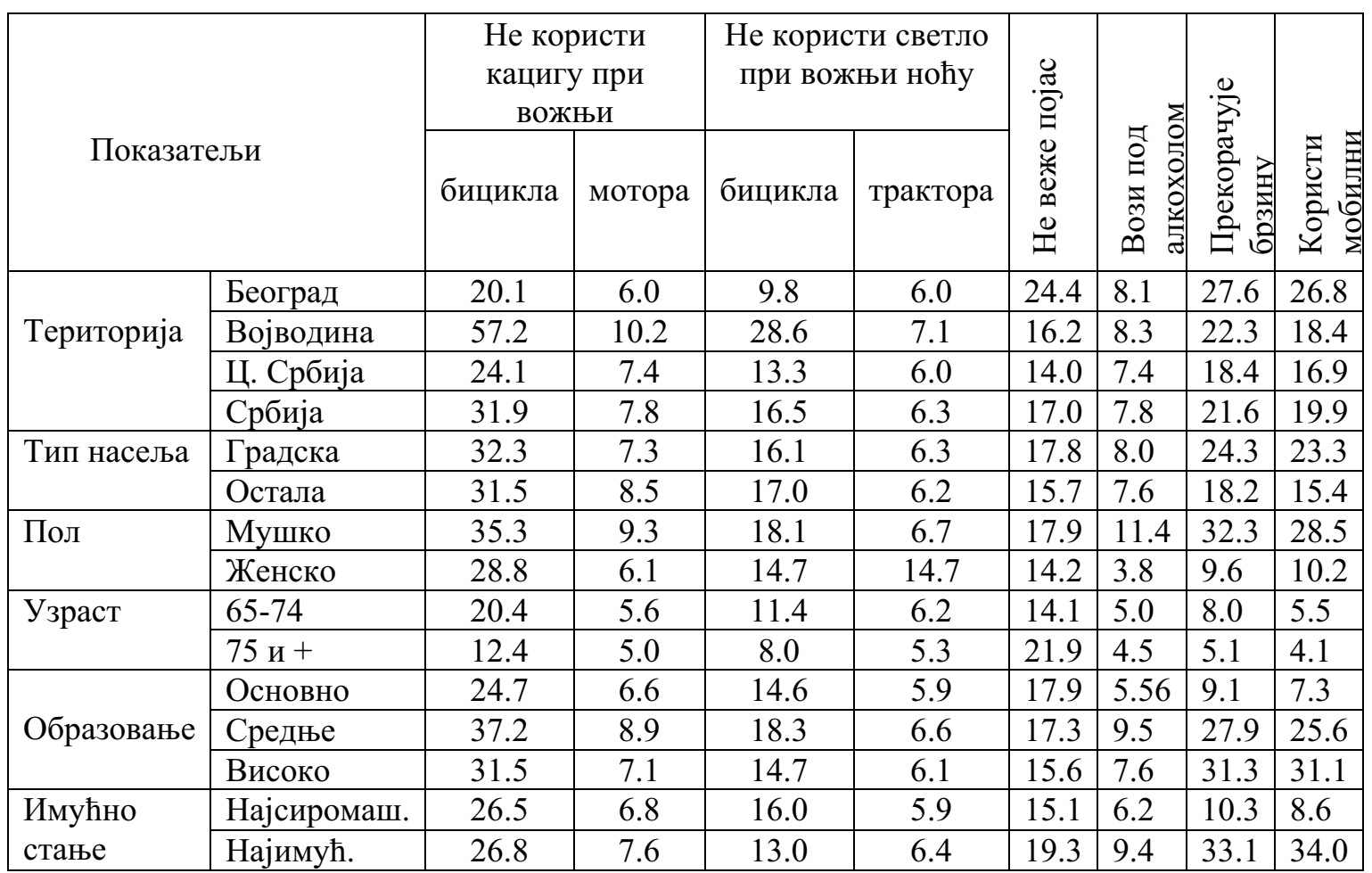

Подаци из табеле 4. такође показују да се старе особе веома ризично понашају у саобраћају - петина не носи заштитну кацигу при вожњи бицикла, а око 5\% при вожњи мотора, затим не користе увек светло при ноћној вожњи бицикла и трактора, а више од петине не веже појас у ауту, вози у алкохолисаном стању 5\% итд. Све је то израженије код становника градских насеља, мушкараца, образованијих и имућнијих становника.
Старе особе су имале саобраћајни удес својом кривицом у $2.6 \%$ случајева, нешто више у млађем узрасту (табела 5).

Као што се из табеле шест може видети, главни узроци саобраћајних удеса су непоштовање саобраћајних прописа (35.4\%), затим неповољна временска ситуација (26.1\%), умор, брза вожња и вожња под утицајем алкохола и лекова.

табела 5. Саобраћајни удеси сопственом кривицум.

\begin{tabular}{|c|c|c|c|c|c|c|c|c|}
\hline \multirow{2}{*}{$\begin{array}{l}\text { Имали } \\
\text { удес }\end{array}$} & \multicolumn{4}{|c|}{ Број анкетираних } & \multicolumn{4}{c|}{$\%$} \\
\hline & $65-69$ & $70-74$ & 75 и + & свега & $65-69$ & $70-74$ & 75 и + & свега \\
\hline Да & 27 & 17 & 9 & 53 & 3.3 & 2.6 & 1.6 & 2.6 \\
\hline Не & 804 & 639 & 572 & 2015 & 96.7 & 97.4 & 98.4 & 97.4 \\
\hline Укупно & 831 & 656 & 581 & 2068 & 100.0 & 100.0 & 100.0 & 100.0 \\
\hline
\end{tabular}


Табела 6. Узроции саобраћајних удеса (\%).

\begin{tabular}{|c|c|c|c|c|}
\hline \multirow{2}{*}{ Узроци } & \multicolumn{5}{|c|}{ Добне групе } \\
\cline { 2 - 5 } & $65-69$ & $70-74$ & 75 и + & Свега \\
\hline Брза вожња & 18.6 & 18.2 & 12.5 & 12.3 \\
\hline $\begin{array}{c}\text { Непоштовање } \\
\text { прописа }\end{array}$ & 37.1 & 27.3 & 50.0 & 35.4 \\
\hline $\begin{array}{c}\text { Вожња под } \\
\text { утицајем } \\
\text { алкохола }\end{array}$ & 5.7 & 4.5 & 12.5 & 6.2 \\
\hline $\begin{array}{c}\text { Неповољни } \\
\text { временски } \\
\text { услови }\end{array}$ & 31.4 & 22.7 & 12.5 & 26.1 \\
\hline $\begin{array}{c}\text { Вожња под } \\
\text { утицајем } \\
\text { лекова }\end{array}$ & 2.9 & 9.1 & - & 4.6 \\
\hline Умор & 14.3 & 18.2 & 12.5 & 15.4 \\
\hline УКУПНО & 100.0 & 100.0 & 100.0 & 100.0 \\
\hline
\end{tabular}

Према подацима из табеле 7 , потврду је имало око $10 \%$ старих особа. Гледано по узрасту, највише повреда имале су особе 65-69 година, а скоро подједнако осталих узраста.

Табела 7. Повреде у задњој години.

\begin{tabular}{|c|c|c|c|c|c|c|}
\hline \multirow{2}{*}{$\begin{array}{c}\text { Добне } \\
\text { групе }\end{array}$} & \multicolumn{3}{|c|}{ Број анкетираних } & \multicolumn{3}{c|}{$\%$} \\
\hline Да & Не & Свега & Да & Не & Свега \\
\hline $65-69$ & 88 & 805 & 893 & 40.6 & 40.1 & 40.1 \\
\hline $70-74$ & 64 & 641 & 705 & 29.5 & 31.9 & 31.7 \\
\hline 75 и + & 65 & 561 & 626 & 29.9 & 28.0 & 28.2 \\
\hline УКУПНО & 217 & 2007 & 2224 & 100.0 & 100.0 & 100.0 \\
\hline
\end{tabular}

Најчешће место повређивања је у кући $(54.2 \%)$, затим на улици $(20.8 \%)$ и на њиви
- у пољопривреди (11.6\%), док на повреде у саобраћају отпада $3.2 \%$ (табела 8 ).

Табела 8. Место повреде (у\%).

\begin{tabular}{|c|c|c|c|c|}
\hline Место повреде & $65-69$ & $70-74$ & 75 и + & Свега \\
\hline У кући & 51.1 & 58.7 & 53.9 & 54.2 \\
\hline На улици & 18.2 & 23.8 & 21.5 & 20.8 \\
\hline У њиви & 14.8 & 12.7 & 6.2 & 11.6 \\
\hline У саобраћају & 1.1 & 1.6 & 7.7 & 3.2 \\
\hline На послу & 3.4 & - & 1.5 & 1.9 \\
\hline $\begin{array}{c}\text { На другом } \\
\text { месту }\end{array}$ & 11.4 & 3.2 & 9.2 & 8.3 \\
\hline УКУПНО & 100.0 & 100.0 & 100.0 & 100.0 \\
\hline
\end{tabular}


У протеклој години старе особе су у $2.4 \%$ случајева имале тровања, нешто више у млађем узрасту (табела 9).

Табела 9. Тровања у задњој години.
Тровања су најчешће била изазвана храном (68.7\%), затим хемикалијама и лековима (по 6.3\%), и била су учесталија код најстаријих узраста (табела 10).

\begin{tabular}{|c|c|c|c|c|c|c|c|c|}
\hline \multirow{2}{*}{ Тровања } & \multicolumn{4}{|c|}{ Број анкетираних } & \multicolumn{4}{c|}{$\%$} \\
\cline { 2 - 10 } & $65-69$ & $70-74$ & 75 и + & свега & $65-69$ & $70-74$ & 75 и + & свега \\
\hline Да & 24 & 19 & 10 & 53 & 2.7 & 2.7 & 1.6 & 2.4 \\
\hline Не & 867 & 685 & 618 & 2170 & 97.3 & 97.3 & 98.4 & 97.6 \\
\hline Укупно & 891 & 704 & 628 & 2223 & 100.0 & 100.0 & 100.0 & 100.0 \\
\hline
\end{tabular}

Табела 10. Узрочи тровања (\%).

\begin{tabular}{|c|c|c|c|c|}
\hline $\begin{array}{c}\text { Тровања } \\
\text { изазвана }\end{array}$ & $65-69$ & $70-74$ & 75 и + & Свега \\
\hline Храном & 68.4 & 65.0 & 77.8 & 68.7 \\
\hline Хемикалијама & - & 10.0 & 11.1 & 6.3 \\
\hline Лековима & 5.3 & 5.0 & 11.1 & 6.3 \\
\hline Друго & 26.3 & 20.0 & - & 18.7 \\
\hline Укупно & 100.0 & 100.0 & 100.0 & 100.0 \\
\hline
\end{tabular}

Кад погледамо детаљније повреде по месту повређивања, територијалним деловима Србије, типу насеља, полу, образовању и имућном стању, запажа се да су повреде погађале $8.3 \%$ старих особа, знатно више у Војводини, мушкараца, мање образованих и најсиромашнијих ста- новника. Највише повреда је било у кући $(4.8 \%)$ и то знатно више у Војводини, онда код жена и сиромашнијих старих лица. На другом месту су повреде у пољу - на њиви (2.4\%), више мушкараца, сеоског становништва, мање образованих и сиромашнијих (табела 11).

Табела 11. Место повреде у задњих 12 месеци.

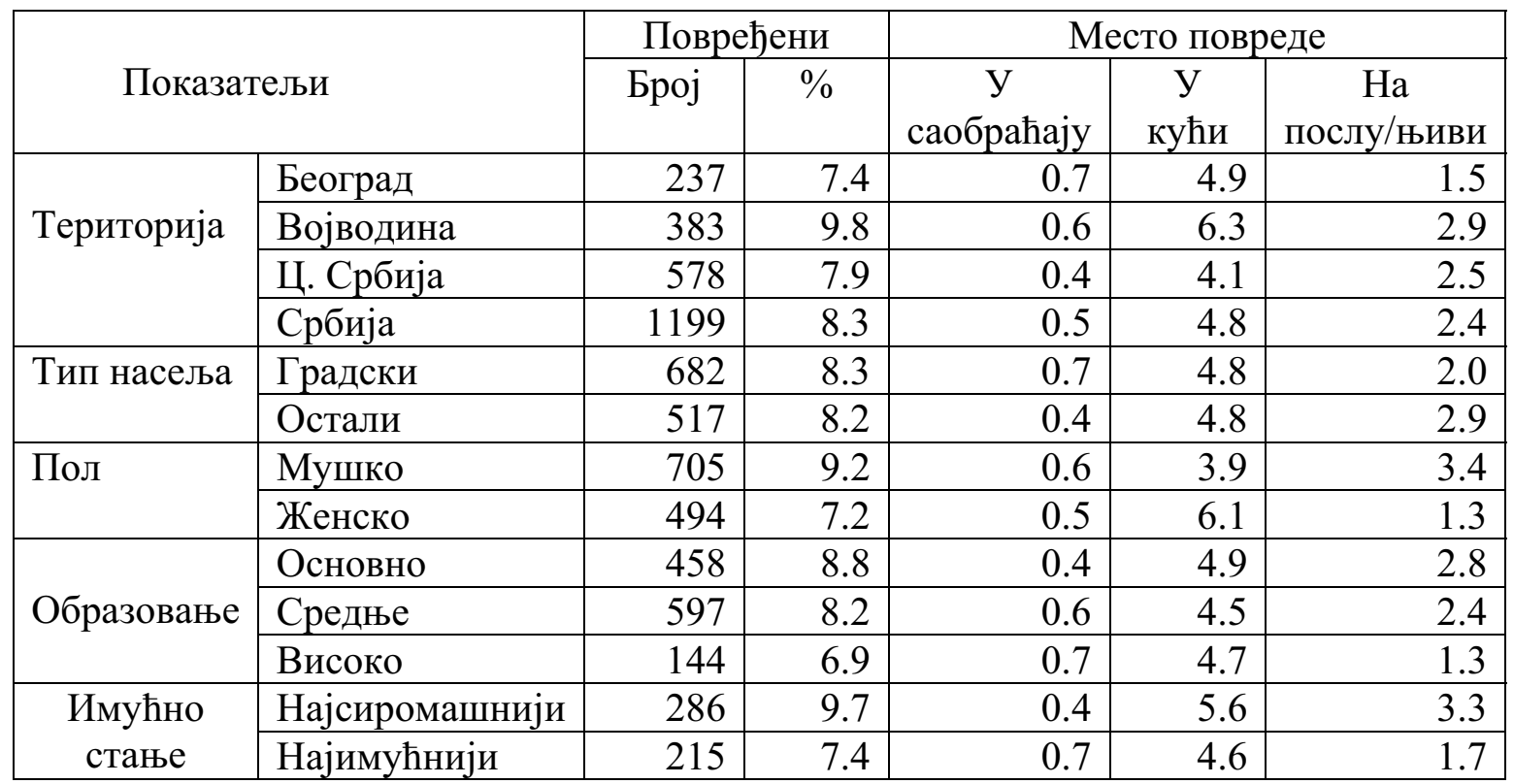


При повређивању прва помоћ није пружана кодчетвртинеповређених, знатновише код градских насеља, жена, најстаријих, најобразованијих и најимућнијих старих лица. Прва помоћ је најчешће пружана у дому здравља и болници. У дому здравља је пружана највише сеоском становништву, мушкарцима, млађим, мање образованим, сиромашнијим становницима, а у болници обрнуто. Иначе прву помоћ је у 70\% случајева пружала здравствена служба, у $1.5 \%$ приватни лекар, у $2.1 \%$ народни исцелитељ.

Табела 12. Место пружања прве помоћи код повреда (у\%).

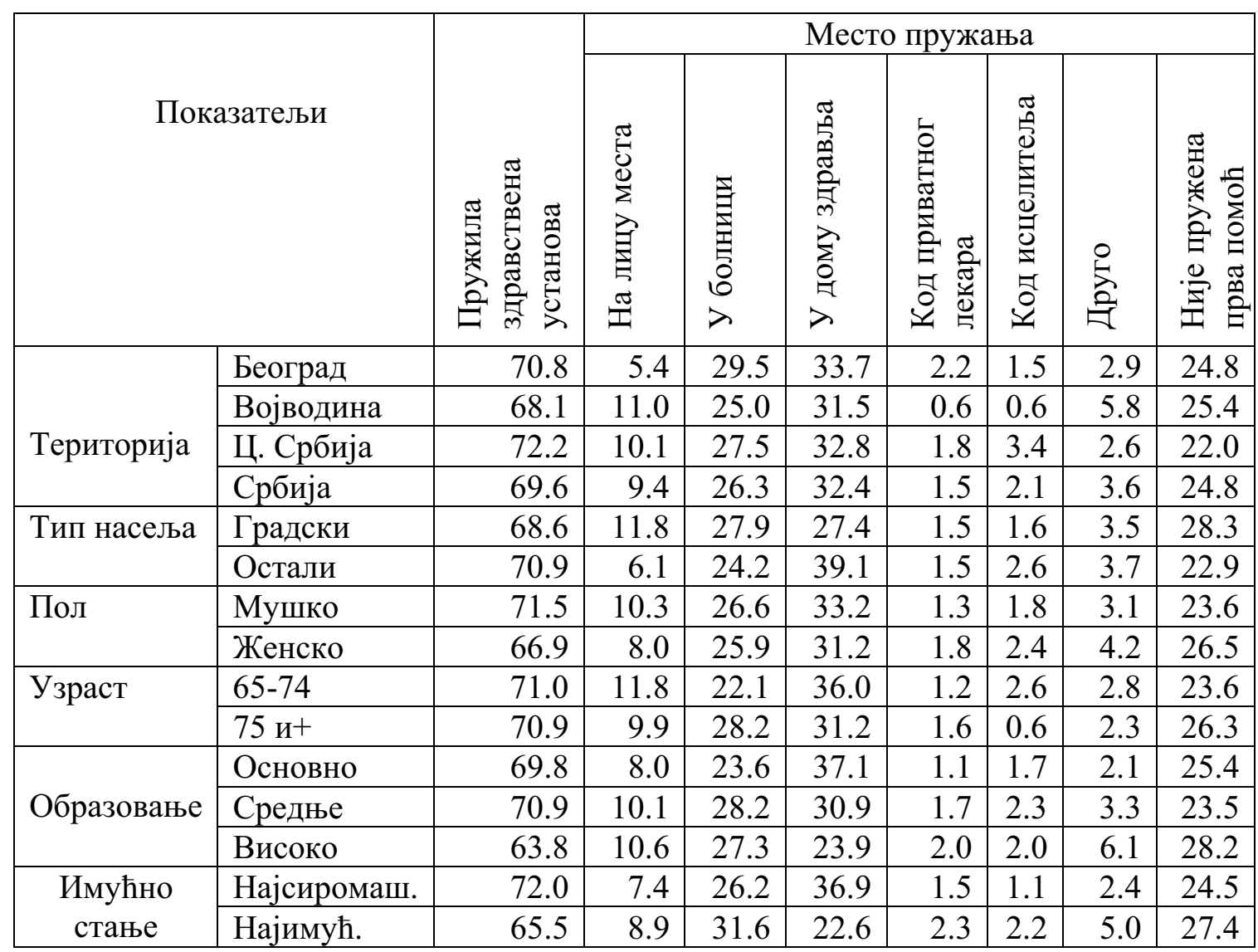

Што се тиче исхода повреда и тровања, оне се углавном завршавају излечењем $(61.3 \%)$ и побољшањем (32.8\%), а само
4.7\% трајном неспособношћу (табела 13 ). У односу на узраст старих особа нема изражених разлика.

Табела 13. Исход повреде и тровања (у\%).

\begin{tabular}{|c|c|c|c|c|}
\hline \multirow{2}{*}{ Исход } & \multicolumn{4}{|c|}{ Добне групе } \\
\cline { 2 - 5 } & $65-69$ & $70-74$ & 75 и & Свега \\
\hline Излечење & 61.5 & 61.7 & 60.6 & 61.3 \\
\hline Побољшање & 32.7 & 33.4 & 32.4 & 32.8 \\
\hline $\begin{array}{c}\text { Трајна } \\
\text { неспособност }\end{array}$ & 3.9 & 3.7 & 7.0 & 4.7 \\
\hline Други & 1.9 & 1.2 & - & 1.2 \\
\hline УКУПНО & 100.0 & 100.0 & 100.0 & 100.0 \\
\hline
\end{tabular}




\section{ЗАКЈЉУЧАК}

Старе особеу $23.7 \%$ случајева имају положен возачки испит и возе разна превозна средства, најчешће бицикл, аутомобил и трактор. При вожњи у добром проценту не користе заштитна средства - кацигу при вожњи бицикла $37.9 \%$, при вожњи мотора $5.1 \%$, затим не користе светла при вожњи бицикла и трактора ноћу, не вежу појас (17\%), возе под утицајем алкохола, прекорачују дозвољену брзину и користе мобилни телефон при вожњи.

Због таквог ризичног понашања саобраћајни удес својом кривицом имало је $2.6 \%$ старих особа, нешто више у млађем узрасту. Најчешћи узроци удеса били су непоштовање саобраћајних прописа (35.4\%), лоши временски услови, брза вожња и умор. Повреде у претходној години

\section{ЛИТЕРАТУРА}

1. Тимотић Б. и сарадници, Сочијална медицина, Веларта, Београд, 2000.

2. Тимотић Б, Увод у медицину, Елит медика, Београд, 2004.

3. Перуновић П. и сарадници, Економско-финансијске могућности коришћена здравствене заштите становништва Србије, Здравствена заштита, 2009; 38/2: 47-52.

4. Обрадовић М. и сарадници, Хигијенске навике и здравље старих лища,

Геронтологија 2006; 1: 144-149.

5. Чомић Н. и сарадници, Здравствени ризици у старости, Геронтологија, 2006; 1: 138-143.

6. Тимотић Б. и сарадници, Превенција и очуване здравља у старости. Зборник уводних реферата VII националног имало је око $10 \%$ старих особа, најчешће у кући (54.2\%), на улици (20.8\%) и на њиви $(11.6 \%)$.

Поред повреда, 2.6\% старих особа је имало и тровања у претходној години, која су углавном изазвана храном, ређе хемикалијама и лековима.

При повређивању прва помоћ није примењена код четвртине повређених, а иначе је око $70 \%$ случајева пружала здравствена служба, и то најчешће у дому здравља највише из сеоских насеља, мушкарцима, млађим, мање образованим и сиромашнијим, а у болницама је обрнуто. У осталим установама је врло ретко пружана хитна помоћ при повредама.

Исход повреда и тровања је излечење $(61.3 \%)$ и побољшање $(32.8 \%)$, док је само $4.7 \%$ имало трајне последице. геронтолошког конгреса, Врњачка Бања, 9-12. мај 2006, Београд, 2006, 89-94.

7. Тимотић Б, Јањић М, Примарна здравствена заштита, Елит медика, Београд, 2002.

8. Радосављевић-Светозаревић Ј. и сарадници, Остваривање здравствене заштите старих лииа, Геронтологија, 2006; 1: 130-133.

9. Тимотић Б. и сарадници, Кућно лечење и здравствена нега старих лица, Новине у унапређивању квалитета живота у старости, Инструктивна геронтолошка едиција, Геронтолошко друштво Србије, Београд, 2004; 153-158.

10. Ерић-Јовановић Р. и сарадници, Локализачија најчешћих фрактура код старих људи, Геронтологија, 2006; 1: 107-111.

Контакт: Мариола Обрадовић, Завод за заштиту радника железнице Србије 